DOI: 10.15642/JIIS.2020.14.1.51-76

\title{
THE EXERTED AUTHORITY OF KIAI KAMPUNG IN THE SOCIAL CONSTRUCTION OF LOCAL ISLAM ${ }^{1}$
}

\author{
Wiwik Setiyani | UIN Sunan Ampel Surabaya - Indonesia \\ wiwiksetiyani@uinsby.ac.id
}

\begin{abstract}
Traditional authority is still the main reference as represented by the Kiai Kampung. Intense communication with the community and moral superiority and examples in solving various community problems are parts of how the Kiai Kampungs hold, maintain, and exercise their traditional authority. This article seeks to explain the authority of the Kiai Kampungs in Ngawi East Java and their role in developing and socially constructing local Islam in Java. The method used refers to historical-sociological studies with a phenomenological approach. This study reveales that the Kiai Kampungs have socially constructed local Islam based on the results of their thought and study authoritatively. Local Islam is a manifestation of an Islamic development model that accommodates local wisdom. Kiai Kampungs are referred to as "charismatic leaders" who have remarkable power to socially determine local Islam in the Kiai's perspective. In certain degree of analysis, the role of the Kiai Kampung indirectly has the potential to color the growth and development of global Islam.
\end{abstract}

Keywords: Authority of kiai, social consrtuction, local Islam

\section{Introduction}

The development of Islam in a local context of Indonesia is inseparable from the role of the $\mathrm{Kiai}^{2}$ (ulama of local Islam) who

\footnotetext{
1 For the accomplishment of the final version of this article, I would send my warmest gratitude to scholars such as Akh. Muzakki and and Masdar Hilmy who commented and facilitated me in making this article possible for publication.

2 The term Kiai does not originate from Arabic but from Javanese, which has sacred, great and revered meaning. The title of Kiai is given to men of old age and wise attitude. Also, the title of Kiai is given to "sacred" and enhanced objects, including spears. See Ahmad Shobiri Muslim, "Urgensi Materi Khatib Jum'at Kiai-Kiai
} 
developed their da'wah in various ways. Kiai Kampung (local Muslim Kiai) as a term under the category of Kiai in question is defined as a figure who has authority ${ }^{3}$ and has been transformed for certain reasons; sometimes Kiai Kampung becomes a $\mathrm{Kiai}^{4}$ and someday it can be transformed into a traditional ritual leader, even, it becomes the main reference in solving community problems. Kiai's relationship with the community is not only limited to religious relations, but also community leaders. ${ }^{5}$ The superiority of morality and values of wisdom are the guidance of society. ${ }^{6}$ The Kiai's authority has increasingly established his authority as the agent of the social construction of local Islam ${ }^{7}$ in Java.

Islam and Javanese culture cannot be separated between the two because they interact with each other. ${ }^{9}$ Local Islam is a cultural product, in the form of Kiai's creative ideas that can form traditions ${ }^{10}$ and give birth to Islamic civilization. Local Islamic construction is a contribution of Kiai in coloring the development of Islam in the archipelago. Local Islamic diversity explains the inclusivism of people who accept diversity as diversity. The role of religious leaders is a

Kampung sebagai Upaya Gerakan Deradikalisasi Agama di Kabupaten Kediri," Spiritualita, 2, 1 (2018), pp. 101-120; Murtado Hadi, Jejak Spiritual Kiai Jampes (Jakarta: Pustaka Pesantren, 2008), pp. 87-90. Saifullah, KH. Badri Mashduqi: Kiprah dan Keteladanan (Yogyakarta: LKiS, 2008), pp. 197-200.

3 Didi Pramono, "The Authority of Kiai Toward the Santri: A Review of Gender Construction at Pondok Pesantren," Komunitas: International Journal of Indonesian Society and Culture, 10, 1 (2018), pp. 92-100.

4 Akmal Mundiri and Afidatul Bariroh, "Transformasi Representasi Identitas Kepemimpinan Kiai dalam Hubungan Atasan dan Bawahan," Al-Idarab: Jurnal Kependidikan Islam, 8, 2 (2018), pp. 234-255.

5 M. Ali Andrias, et al., "Model Kepemimpinan Politik Kiai: Studi Peran Kiai dalam Pergeseran Perilaku Politik Massa NU PKB dan PPP," Politika: Jurnal Ilmu Politik, 7, 2 (2016), pp. 21-33.

${ }^{6}$ Ronald A. Lukens-Bull, "Teaching Morality: Javanese Islamic Education in a Globalizing Era," Journal of Arabic and Islamic Studies, 3 (2000), pp. 26-47.

7 Leif O. Manger, Muslim Diversity: Local Islam in Global Contexts (New York: Routledge, 2013), pp. 60-75.

9 José María Díez-Esteban, Jorge Bento Farinha, and Conrado Diego García-Gómez, "Are Religion and Culture Relevant for Corporate Risk-Taking? International Evidence,” Brq Business Research Quarterly, 22, 1 (2019), pp. 36-55.

10 James J. Fox and A. G. Muhaimin, "Foreword," The Islamic Traditions of Cirebon, Ibadat and Adat Among Javanese Muslims (Canberra: ANU Press, 2006), pp. 21-30. 
dominant factor in constructing and developing Islam with its local identity. ${ }^{11}$

In an Indonesian context, the development of Islam in Java was brought by walisongo (nine Muslim figures) with various features that combined local values and Islam. ${ }^{19}$ Furthermore, pesantren (a place to study Islam) becomes a means of caring for people who are led by a Kiai. 20 In its development, Kiai kampung has full authority in constructing local Islam with the approach of marginal people ${ }^{21}$ or bromocorah (drunkards, gamblers, or bad attitudes that are contrary to religious and community norms).

The Kiai Kampung in traditional Islamic practices imposes marginal behavior. Local Islam is still a primitive attraction to explain how Islam in Java can develop rapidly. The life of the Kiai of the village becomes an attraction to find uniqueness in constructing Islam so that it is quickly understood and accepted by the community through the prescriptive authority. The personal approach of the Kiai Kampung and community interaction are the right choices to explain how local Islam is presented.

The focus of this study looks at how the Kiai's authority interacts with the community in developing Islam. It takes Ngawi, one of the regions which is quite far from the center of governatorial political power but plays a key role in bridging East Jawa and Central Java, as a locus of analysis, allowing a room for exercising the Kiai's authority in traditional Javanese Muslims. The sociology-phenomenology approach becomes the choice in seeing the Kiai's authority in order to find a local Islamic construction.

11 Masdar Hilmy, "Towards A Religiously Hybrid Identity? The Changing Face of Javanese Islam," Journal of Indonesian Islam, 12, 1 (2018), pp. 45-68.

19 Names of Walisongo: 1) Maulana Malik Ibrahim, 2) Raden Rahmat (Sunan Ampel), 3) Raden Qasim (Sunan Drajat), 4) Ja'far Shadiq (Sunan Qudus), 5) Raden Makdum Ibrahim (Sunan Bonang), 6) Raden Paku (Sunan Giri), 7) Raden Sahid (Sunan Kalijaga), 8) Raden Umar Sahid (Sunan Muria), 9) Syarif Hidayatullah (Sunan Gunung Jati). See Dewi Evi Anita, "Walisongo: Mengislamkan Tanah Jawa (Suatu Kajian Pustaka)," Wahana Akademika: Jurnal Studi Islam dan Sosial, 1, 2 (2016), pp. 243-266.

20 Pradjarta Dirdjosanjoto, Memelihara Umat; Kiai Pesantren-Kiai Langgar di Jawa (Yogyakarta: LKiS, 1997), pp. 18-30.

21 Ratnah Rahman, "Peran Agama dalam Masyarakat Marginal," Sosioreligius, 4, 1 (2019), pp. 81-89. 


\section{The Socio-Religious Perspective of the Local Muslim Community in Ngawi}

Community life in villages is quite dominant in the agricultural economy namely; farming rice, vegetables, and various other staple crops (corn, soybean, cassava, beans). ${ }^{22}$ Society depends on nature to fulfill basic needs so as to avoid poverty. ${ }^{23}$ The income from agriculture is useful to fulfill the needs of family life and some are donated to the mosque voluntarily on the instructions of the ulema. Management of public funds can be used for celebrating the prophet's birthday activities that are managed transparently and for the maintenance of the mosque. ${ }^{24}$ Community compliance to provide infaq is believed to bring good luck ${ }^{25}$ even though, the community is not a devout Muslim.

The condition of the people in Ngawi especially in the villages are marginal people or also called bromocorah. ${ }^{26}$ Ngawi community is identified as a mataraman community that has a different culture from other communities, The social status inherent in the village community is mostly from ex-PKI (Indonesian communist party) ${ }^{28}$ extended families, but gradually the stereotype disappears as post-reformation is vulnerable to conflict. ${ }^{29}$ Society prefers togetherness and avoids conflicts because Islam gives space to anyone in difficult conditions.

In the cultural aspect of the community, they still maintain the traditions of their ancestors including clean village traditions with dances followed by alcoholic beverages (arak), childbirths are still colored by playing cards that lead to gambling. ${ }^{30}$ Village communities with these activities are classified as marginal or traditional

\footnotetext{
22 Interview with Kumini, Ngawi, 12 March 2019.

23 Mansyur Nawawi et al., "The Village Kalesang Program as a Poverty Alleviation Community," International Journal of Scientific and Technology Research, 9, 03 (2020), p. 6.

24 Interview with Maskuruddin, Ngawi, 14 March 2019.

25 The Qur'an: 2: 272.

26 Interview with Jarwati, Ngawi, 15 March 2019.

28 Interview with Slamet, Ngawi, 16 March 2019.

29 Siti Aliyuna Pratisti, Deasy Silvya Sari, and Taufik Hidayat, "Narasi Populer Indonesia Pasca Reformasi: Sebuah Kajian Psikokultural," Umbara, 4, 2 (2019), pp. 89100.

30 Interview with Jono, Ngawi, 17 March 2019.
} 
communities. ${ }^{31}$ Intense communication with a persuasive approach between religious leaders and the community begins to diminish and is open to Islam. ${ }^{32}$ Through the community harmony approach, trying to eliminate stigmatization of marginal groups through the role of religious leaders as an effort to build characters (abklaq) ${ }^{33}$ with its spiritual foundation.

The religion adopted by the community is Islam but, limited to formality and in general, has not touched on the implementation of religious teachings. ${ }^{34}$ Geertz's perspective, religion is cultural values that have meaning (interpretation of experience and behavior), by integrating both (religion and local culture) called syncretism. ${ }^{35}$ Cultural acculturation with Islam has been inherent in Javanese society which has been labeled as home-grown in the Islamic tradition. ${ }^{36}$ Religion is still limited to teachings not, as religious behavior. ${ }^{37}$ Understanding of the principle of monotheism (oneness of God) and fiqh (law) has not been understood even, the prayer readings still need guidance. ${ }^{38}$ Therefore, a Muslim must understand the doctrine of religious teachings as a guide to his life by carrying out the commands and prohibitions of Allah and believes that, the doctrine of Islamic teachings is a religion that brings peace to the people..$^{39}$

Getting to know Islam begins with the foundation of the faith and recognizes that, Allah created and killed all beings. ${ }^{40}$ The recognition

31 Ratnah Rahman, "Peran Agama dalam Masyarakat Marginal," Sosioreligius, 4, 1 (2019), pp. 81-89.

32 Interview with Sumarsono, Ngawi, 18 March 2019.

33 Ida Umami, "Peran Tokoh Agama dalam Pembinaan Harmonisasi Kehidupan dan Akhlak Masyarakat di Kota Metro Lampung," Fikri: Jurnal Kajian Agama, Sosial dan Budaya, 3, 1 (2018), pp. 259-276.

34 Interview with Sumarsono, Ngawi, 19 March 2019.

35 Clifford Geertz, The Religion of Java (Chicago: University of Chicago Press, 1976), pp. 67-78.

36 Kunawi Basyir, “The 'Acculturative Islam' as a Type of Home-Grown Islamic Tradition: Religion and Local Culture in Bali," Journal of Indonesian Islam, 13, 2 (2019), pp. 326-349.

37 Wiwik Setiyani, "Agama sebagai Perilaku Berbasis Harmoni Sosial; Implementasi Service Learning Matakuliah Psikologi Agama," Community Engagement (2016), p. 26.

38 Interview with Wajinah, Ngawi, 20 March 2019.

39 Ahmad Asroni, "Islam dan Bina Damai: Ikhtiar Membumikan Doktrin Islam yang Rahmatan Lil "Alamin," Titian: Jurnal Ilmu Humaniora, 3, 2 (2019), pp. 222-240.

40 The Qur'an: 3: 27. 
of Islam in the village community in Ngawi is still limited to identity and deviates from Islamic teachings. Community behavior such as gambling, adultery, stealing, and drinking alcohol ${ }^{41}$ which is the enemy of the community still colors people's lives. Morality is still far from the values of spirituality because of this, religion must have a good moral effect on human actions. ${ }^{42}$ Islam is only a symbol that is understood as a culture in line with the cultural approach taken by Geertz about religion. ${ }^{43}$

Islamic knowledge is still limited to reading the Qur'an which is far from perfection. Religious studies are not interesting unless they are delivered by lecturers who are popular with their cuteness. For example; Kyai Ma'ruf Islamuddin. ${ }^{44}$ Islamic learning has not become a cultural community, routine worship is still not disciplined, and the young generation of children studying in public schools whose religious content is limited to formality. ${ }^{45}$ To attract interest in learning Islam can be done with stories or stories like verses of love. These works became Islamic publications as a medium for transmitting religious ideas. The method of transmitting Islam through stories is a form of publication of Islamic story books segmented for teenagers. ${ }^{46}$ The young generation must get attention in understanding Islam in an interesting and fun way.

Mosque as a place of worship is only dominated by elderly people. While youth and children still have not carried out their religious duties on a regular basis. ${ }^{47}$ The effect of worship in congregation in a mosque can shape the collectivity ${ }^{48}$ of the community and increase

\footnotetext{
41 Interview with Sri Muryati, Ngawi, 20 March 2019.

42 Paul Bloom, "Religion, Morality, Evolution," Annual Review of Psychology, 63, 1 (2012), pp. 179-199.

43 Clifford Geertz, The Interpretation of Cultures (New York: Basic Books, 1973), pp. 2325.

${ }^{44}$ Kyai Ma'ruf; A caretaker of Walisongo Islamic boarding school, Sragen, Central Java and a well-known lecturer with traditional language styles and distinctive musical accompaniment. Interview with Kumini, Ngawi, 21 March 2019.

45 Interview with Khudhori, Ngawi, 21 March 2019.

46 Akh. Muzakki, "Transmitting Islam Through Stories: The Sociology of Production and Consumption of Islam in Novel Literature," Journal of Indonesia Islam, 11, 2 (2017), p. 61.

47 Interview with Anas, Ngawi, 22 March 2019.

48 Stormie Omartian, The Power of Praying Together: Prayer and Study Guide (USA: Harvest House Publishers, 2003).
} 
interactions that require one another even, having the significance of discipline. The mosque has multiple functions including worship, reading holy Qur'an, management, character building, and organizing ${ }^{49}$. However, most mosques in the village are still limited to praying, reading the Qur'an, and performing kenduri (eating together) during Islamic celebration. ${ }^{50}$ The mosque empowerment program can be enhanced by revitalizing mosque functions and optimizing community activities. ${ }^{51}$

Youth Organization or youth generation as agents of change are limited to social activities or temporary marriage events, religious commemoration activities are not well organized. ${ }^{52}$ The forms of youth creativity ${ }^{53}$ are absolutely necessary for building a dynamic society to build the progress of civilization. One of the most popular creativities is the reog dance (dance name from Ponorogo) which is livened up with intoxicating drinks which are done once a year by going around the village and passing the courtyard (in front of the mosque). ${ }^{54}$ The activities of village traditions, cause public unrest and conflict with the morals of a Muslim. Woodward identifies tradition with his inseparable locality culture ${ }^{55}$. Geertz's perspective of abangan people who tend to be acculturative ${ }^{56}$ with their local traditions.

Enthusiastic people in religious activities can be found in the group or majelis ta'lim yasin tahlil (the name of the Qur'an and reading tahlil) which is carried out once a month on Saturday evenings Sunday. This activity was followed by elderly mothers, most of whom were unable

49 Syamsul Kurniawan, "Masjid dalam Lintasan Sejarah Umat Islam," Jurnal Khatulistiwa - Journal of Islamic Studies, 4, 2 (2014), p. 169.

50 Interview with Zaini, Ngawi, 23 March 2019.

51 Dzurwatul Muna, "Pemberdayaan Masyarakat melalui Optimalisasi Fungsi Masjid sebagai Pusat Kegiatan Masyarakat di Dusun Sawahan," Prosiding Konferensi Pengabdian Masyarakat, 1 (March 2019), pp. 285-287.

52 Interview with Kumini, Ngawi, 24 March 2019.

53 Fajar Susanto and Triana Novitasari, "Bentuk Kreativitas Pemuda Karang Taruna dalam Pembangunan Desa Bening," Jurnal Penamas Adi Buana, 2, 2 (2019), pp. 25-28.

54 Interview with Agus, Ngawi, 25 March 2019.

55 Mark Woodward, "Java, Indonesia and Islam," Muslims in Global Societies Series (the Netherlands: Springer, 2011), pp. 1-8.

56 Clifford Geertz, The Religion of Java (Chicago and London: The University of Chicago Press), pp. 30-33. 
to read the Qur'an in Arabic. ${ }^{57}$ The ta'lim assembly has the role of increasing religious understanding so that it will have an impact on changes in religious behavior. In addition, it becomes a propaganda media to improve the quality of worship with an intensive planning and communication strategy. ${ }^{58}$ In line with Geertz, holding fast to the patterns of organization of local community trust ${ }^{59}$ even though, the majelis taklim has developed in the community.

The socio-religious of the village community explained that religious teachings are a formality and local traditions of Islam try to strike a balance between religion and culture. The Javanese community of Geertz's perspective consists of three parts; abangan, santri and priyayi. And abangan practices of Islam are more syncretic if compared to the more orthodox santri group. Islamic tradition has a variety of variants between local traditions with Islam giving birth to syncretistic Islamic theories. ${ }^{60}$ In line with Beatty's writing ${ }^{61}$, Mulder used the concept of locality ${ }^{62}$ and Mark Woodward with his acculturative Islam. ${ }^{63}$ The Islamic community of the village still needs a process of assistance and empowerment in upholding character in accordance with Islamic spirituality. Marginal communities are one asset that must be empowered with a personal approach. Good potential must be pursued and bad potential suppressed in wise ways. The local Islamic community is part of the local Kiai's design to change conventional patterns of life into religion. The role of the ulama in understanding Islam can be explained by conveying religious messages easily to be understood and practiced both, matters of worship and in the activities of daily life.

\footnotetext{
57 Ability to Recite the Qur'an at Taklim Assembly only 4-6 people fulfill the clarity of recitation. Interview with Kunik, Ngawi, 25 March 2019.

58 Idawati Idawati and Benni Handayani, "Communication Strategy Planning of Majelis Taklim in Implementation Recitation Program," International Journal of Media and Communication Research, 1, 1 (2020), pp. 41-46.

59 Clifford Geertz, "The Javanese Kijaji: The Changing Role of a Cultural Broker," Comparative Studies in Society and History, 2, 2 (1960), pp. 228-249.

${ }^{60}$ Geertz, The Religion of Java, pp. 32-34.

61 Andrew Beatty, Varieties of Javanese Religion an Antropological (New York: Cambridge University Press, 2003), p. 25.

62 Niels Mulder, Mistisime Jawa, Ideologi Indonesia (Yogyakarta: LKIS, 2001), p. 35.

63 Woodward, "Java, Indonesia and Islam", pp. 6-8.
} 


\section{Kiai Kampung and the Development of Day-to-Day Local Islam}

Conveying a religious message requires a leader figure who has sublime knowledge and behavior or moral heights so that he becomes an example for his followers. The existence of the Kiai is not formally or informally chosen but, flows because of his charisma and superiority of personality and inherent prescriptive or bossy attitudes.

Kiai or religious leaders (ulama) teach religious values and local wisdom that have been inherited in people's daily lives. ${ }^{64}$ The term Kiai is not from Arabic but from Javanese, which has a sacred, great, and revered meaning. The title of Kiai is given to men who are elderly and wise. Other than that, also given to sacred objects and is enhanced like; keris and spear. ${ }^{65}$ Kiai Kampung is also called local Islamic scholars, namely, as figures who have authority in society. ${ }^{66}$ Religious leaders have undergone a transformation, sometimes becoming Kiai and in certain conditions can turn into a sage or traditional ritual leader. ${ }^{67}$ Kiai's relationship with the community is not only limited to religious relations, but also community leaders. ${ }^{68}$ The Kiai's authority has increasingly established his authority as a local Islamic construction in Java ${ }^{69}$ has colored the development of global Islam. ${ }^{70}$

The Kiai's life becomes one of the indicators to find the Kiai's subject which can be used as a role model or guide for the community. The scholars who were scattered in the villages of Ngawi were surveyed with technique random sampling 71 namely three villages: (Gemarang, Gelung, and Ngrambe). The Kiai subjects studied in

\footnotetext{
${ }^{64}$ Muhammad Alfien Zuliansyah, "Sowan Kiai, Komunikasi Perspektif Islam-Jawa," Komunikator, 9, 2 (2017), pp. 95-104.

65 Ahmad Shobiri Muslim, “Urgensi Materi Khatib Jum'at Kiai-Kiai Kampung sebagai Upaya Gerakan Deradikalisasi Agama di Kabupaten Kediri,” Spiritualita, 2, 1 (2018), pp. 101-120.

66 Didi Pramono, "The Authority of Kiai Toward the Santri: A Review of Gender Construction at Pondok Pesantren," Komunitas: International Journal of Indonesian Society and Culture, 10, 1 (2018), pp. 92-100.

${ }^{67}$ Mundiri and Bariroh, "Transformasi Representasi Identitas Kepemimpinan Kiai," pp. 234-255.

68 Andrias, "Model Kepemimpinan Politik Kiai," pp. 21-33.

69 Manger, Muslim Diversity, pp. 224-243.

70 Ed Husain, The House of Islam: A Global History (London: Bloomsbury Publishing, 2018), pp. 233-235.

${ }^{71}$ Earl Babbie, The Basics of Social Research (n.p.: Cengage Learning, 2007), p. 224.
} 
general have the same background in life, in the aspects of education, economics, and involvement in politics and social culture. The figure of the Kiai Kampung does not have a lineage from a large Ulama group. ${ }^{72}$ The Kiai of the village has the potential to innovate independently with hard work and efforts in community building. ${ }^{73}$

Socio-economic conditions Kiai has a very simple life with a source of livelihood in trading, farming, and continuing to carry out social actions voluntarily. ${ }^{74}$ The behavior of the Kiai in each village won the sympathy of the community. The mission of enlivening the mosque with prayer in congregation and teaching reading the Qur'an for children and parents. The religious values taught by Kiai gives enthusiasm to people's lives. ${ }^{75}$

Islamic da'wah is carried out with a personal approach especially to the bromocorah group. Interpersonal communication becomes a da'wah media carried out effectively and gives an impression to individuals. ${ }^{76}$ The role of the Kiai in the political aspect teaches about leaders who can be trusted by the community. The Kiai does not intervene in the political sphere but, instead, provides support in the form of prayer to anyone who visits him..$^{77}$ Open attitude and taking no side with those who want to seek political office is amoral nobility or Kiai's character. ${ }^{78}$

In the cultural aspect, the Kiai provides the widest possible space for the community to be creative with existing traditions. Reog's art activities carried out at the 'nyadran' village clean-up activity continued and allowed the community to use alcoholic drinks. ${ }^{79}$ Freedom of expression of the community raises the pros and cons of which the

\footnotetext{
72 Three Kiais who were the research subjects: Kiai Anas, Kiai Miskan dan Kiai Sumarsono. (they had been interviewed for three months, March - June 2019.

73 Besse Ruhaya, "The Values of Religious Education at Islamic University as the Ulema Cadre Institution," International Journal of Innovative Studies in Sociology and Humanities, 4, 5 (2019), pp. 1-4.

74 Interview with Sumarsono, Ngawi, 28 March 2019.

75 Mita Octarina and Tina Afiatin, "Efektivitas Pelatihan Koping Religius untuk Meningkatkan Resiliensi pada Perempuan Penyintas Erupsi Merapi," JIP, Jurnal Intervensi Psikologi, 5, 1 (2013), pp. 95-110.

76 Kurniati Abidin, "Komunikasi Interpersonal dalam Dakwah Kelompok Jamaah Tabligh," Al-Din: Jurnal Dakwah dan Sosial Keagamaan, 5, 1 (2020), pp. 118-127.

77 Interview with Miskan, Ngawi, 28 March 2019.

78 Hadi, Jejak Spiritual Kiai Jampes, pp. 2-3.

79 Interview with Sumarsono, Ngawi, 29 March 2019.
} 
majority supports the tradition. Community culture is still rooted in primitive traditions that have local wisdom values by maintaining their identity. ${ }^{80}$ Primitive village traditions are still attached to individual communities so a process is needed to change their views on the acculturative Islamic tradition. ${ }^{81}$

\section{The Construction and Exercises of Kiai Kampung's Socio- Religious Authority}

The role of the Kiai Kampung is very different from that of the pesantren ${ }^{82}$ Kiai. ${ }^{83}$ The Kiai of the village confronts the community with a syncretic Islamic typology that runs interconnected with the local culture. ${ }^{84}$ The Qur'an teacher or religious teacher in the village is a product of Kiai pesantren. Communication between the Kiai and the cleric in providing prescriptive instructions meant that the community followed what Kiai said, whereas the Kiai Kampung accepted the wishes of the people with an Islamic mission to develop and be loved by the community. ${ }^{85}$ The Kiai prescriptive became a role model for the community without rejection that affected the Kiai's authority.

Kiai's leadership experienced a shift, especially in political contestation. ${ }^{86}$ Local politics is a reflection of Kiai Kampung who has the authority to determine government leadership or even become government leaders. ${ }^{87}$ The political contract between the Kiai Kampung and local politicians has an impact on sustainability and synergy

80 Geertz, "The Javanese Kijaji, pp. 228-249.

81 Geertz, The Religion of Java, p. 148.

82 Pesantren represents a mode of religious-based schooling system typical of Indonesia which characteristically has five components: the cleric, the student (santri), the mosque, a boardinghouse and the classic book (kitab kuning). See Pattana Kitiarsa, Religious Commodifications in Asia: Marketing Gods (London: Routledge, 2007).

83 Ahmad Fatoni, "Hubungan antara Kyai Kampung dan Kyai Pesantren," Koran Bhirawa, 17 February 2020.

${ }^{84}$ Geertz, The Religion of Java, pp. 121-129.

85 Ruth A. Berman, Usage-Based Studies in Modern Hebrew: Background, Morpho-Lexicon, and Syntax (Amsterdam, Philadelphia: John Benjamins Publishing Company, 2020), p. 98.

86 Mahfudz Sidiq, "Pergeseran Pola Kepemimpinan Kiai dalam Mengembangkan Lembaga Pesantren," Falasifa: Jurnal Studi Keislaman, 11, 1 (2020), pp. 144-156.

87 Herdy Sahrasad, "Review of Islam, State and Society In Indonesia: Local Politics in Madura by Yanwar Pribadi," Southeast Asian Studies, 8, 2 (2019), pp. 331-335. 
between the community and the Kiai Kampung. The Kiai Kampung authority in local political matters as a mediator and negotiator and is prescriptive in the interests of the region. Religion and government act as socio-political control that can provide protection and balance between the political interests of government and society. ${ }^{88}$

The Kiai's authority focuses on studying the Qur'an and religious studies as a basis for Islamic education. Kiai Hasyim Asy'ari is known as the founder of Nahdlatul Ulama and Indonesian freedom fighter. 89 The Muhammadiyah organization, led by Kiai Ahmad Dahlan, integrates education by adapting Islamic and general science. ${ }^{90}$ The Kiai portrait is a mirror of the village's Kiai authority in teaching Islamic values to face challenges in the modern era.

Islamic education has become one of the most important parts of building the community. Therefore, the Kiai Kampung recruits Qur'an teachers with salaries from zakat, infaq, and sadaqah. ${ }^{91}$ The mosque has a strategic function in exploring the knowledge and symbols of Islam and the administration of Islamic da'wah management. ${ }^{92}$ The Kiai Kampung determine the people chosen to occupy positions in the mosque organization. The words of the Kiai Kampung must be obeyed and obeyed by the community without consultation. ${ }^{93}$ Obedience to Kiai is a moral ethic that is maintained by the community because the role of Kiai's leadership is to shape the character of santri. ${ }^{94}$

The forms of authority of the Kiai Kampung in determining the mosque ta'mir, mosque administrators, and Qur'an teachers were

88 Robert Edward Sterken, "Religion and the State: The Politics of Social Control in Myanmar and the United States," E. Rabe-Hemp Cara and S. Lind Nancy (eds), Political Authority, Social Control and Public Policy (Bingley, UK: Emerald Publishing Limited, 2019), pp. 109-122.

89 Ah. Mutam Muchtar, "Potret Pendidikan Pesantren dalam Film 'Sang Kiai," Jurnal Pemikiran dan Ilmu Keislaman, 2, 1 (2019), pp. 82-124.

90 Satria Setiawan and Budi Sujati, "Gambaran Ahmad Dahlan dan Wahab Hasbullah dalam Pendidikan Islam terhadap Nasionalisme Indonesia," Al-Fikri: Jurnal Studi dan Penelitian Pendidikan Islam, 2, 1 (2019), pp. 28-36.

91 Interview with Maskurudin, Ngawi, 21 November 2019.

92 Adilah Mahmud, "Hakikat Manajemen Dakwah," Palita: Journal of Social Religion Research, 5, 1 (2020), pp. 65-76.

93 Interview with Aniek Mutmainah, Ngawi, 24 November 2018.

94 Mia Kurniati, Miftahus Surur, and Ahmad Hafas Rasyidi, "Peran Kepemimpinan Kiai dalam Mendidik dan Membentuk Karakter Santri yang Siap Mengabdi kepada Masyarakat," Al-Bayan: Jurnal Ilmu Al-Qur'an dan Hadist, 2, 2 (2019), pp. 194-203. 
carried out by acclamation because they did not want any debate or other ideas. ${ }^{95}$ Election by acclamation can eliminate creative ideas in order, avoiding gaps or conflicts. ${ }^{96}$ The Kiai Kampung accelerates and facilitates all forms of activities, even household matters, and determines the implementers of Friday sermons and religious celebrations. ${ }^{97}$ The selection of people who served in religious celebration activities carried out regeneration. Youth and mosques become a means of entertainment ${ }^{98}$ because to provide opportunities for youth in developing mosques by carrying out Islamic arts activities and local traditions..$^{99}$ Islam can collaborate with a variety of arts and culture that can provide benefits to maintain morality and human values in the modern era. ${ }^{100}$

Social-economic problems in the community are directly communicated with the Kiai Kampung. ${ }^{101}$ One village governance program refers to pesantren with the success of socio-economic empowerment that does not abandon the values of local wisdom. ${ }^{102}$ Economic potential in agriculture there is a tradition of slametan ${ }^{103}$ in the fields or at home. Some of the crops are sent to the mosque. The variety of traditions have changed with the modified by Kiai Kampung with its authority. ${ }^{104}$

\footnotetext{
95 Interview with Kumini, Ngawi, 26 November 2018.

96 Logan L. Watts et al., "Minding the Gap between Generation and Implementation: Effects of Idea Source, Goals, and Climate on Selecting and Refining Creative Ideas," Psychology of Aesthetics, Creativity, and the Arts, 13, 1 (2019), pp. 2-14.

97 Interview with Kunik Masrokah, Ngawi, 27 November 2019.

98 Kenneth Roberts, Youth and Leissure (London: Routledge, 2019).

99 Interview with Agus Ghozali, Ngawi, 29 November 2019.

100 Titin Nurhidayati, "Pemikiran Sayyed Hossein Nasr: Konsep Keindahan dan Seni Islami dalam Dunia Pendidikan Islam,” Falasifa, 10, 1 (2019), pp. 27-44.

101 Interview with Basuki, Ngawi, 29 November 2019.

102 Muhammad Nafik Hadiryandono, "Sosial Ekonomi Pondok Pesantren Perspektif Sejarah,” Mozaik Humaniora, 18, 2 (2018), pp. 189-204.

103 Jochem van Den Boogert, "The Role of Slametan in the Discourse on Javanese Islam," Indonesia and the Malay World, 45, 133 (2017), pp. 352-372.

104 Interview with Sri Muryati, Ngawi, 30 November 2018.
} 
The Kiai Kampung authority in the tradition of nyadran or village cleansing ${ }^{105}$ is an interesting phenomenon because it presents many people from various other villages. Its purpose; first, get safety and success in life. Second, good rice plants and many yields. Third, keep away from all disasters. Fourth, strengthen relations between harmonious people (togetherness). Kiai Kampung always inspires and becomes the main reference in the community. ${ }^{106}$ The Kiai Kampung authority consists of all aspects of life and aspects of community interests with their character of wisdom.

The character of the community is influenced by the Kiai Kampung through its authority to modify village traditions including; First, the community is not far from polytheism or kufr. Second, while maintaining tradition with its acculturative. ${ }^{107}$ Third, invite bromocorah or marginal people to adapt more subtly and acceptably to their environment. ${ }^{108}$

The concept of Kiai Kampung authority has contributed to the development of local Islam in Indonesia by accepting people with diverse characteristics. The dynamics of local Islam can enrich the traditional treasures that do not cause conflict in society so that what appears on the surface is Nusantara Islam ${ }^{109}$, grounding Islam and local traditions in Indonesia. The Authority of Kiai Kampung is community obedience to religious leaders. The Kiai Kampung transforms leadership ${ }^{110}$ from religious aspects into solutions to various village problems.

Kiai is a representation of religion because religion can be a theory of self or behavior that will have the functions of systems of thought and action. ${ }^{111}$ The system built in the village community is indirectly

105 Wiwik Setiyani, "Implementasi Psikologi Humanistik Carl Rogers pada Tradisi Lokal Nyadran di Jambe Ngawi Kedunggalar Ngawi," Islamica: Jurnal Studi Keislaman, 12, 1 (2017), pp. 230-257.

106 Interview with Agus Ghozali, Ngawi, 3 December 2018.

107 Umi Sumbulah, "Islam Jawa dan Akulturasi Budaya: Karakteristik, Variasi dan Ketaatan Ekspresif," el-Harakah, 14, 1 (2012), pp. 51-68.

108 Interview with Sumarsono, Ngawi, 3 January 2019.

109 Khabibi Muhammad Luthfi, "Islam Nusantara: Relasi Islam dan Budaya Lokal," Shabib: Journal of Islamicate Multidisciplinary, 1, 1 (2016), p. 1.

110 Mundiri and Bariroh, "Transformasi Representasi Identitas Kepemimpinan Kiai.

111 Paul C. Vitz, Religion as Psychology: The Cult of Self-Worship (USA - Michigan: William

B. Eerdmans Publishing Company, 1994), p. 32. 
attached to the authority of Kiai Kampung. The effectiveness of the charismatic leader ${ }^{112}$ in Weber's perspective reinforces that, the Kiai Kampung is able to obtain these gains independently. The Kiai has authority, of course, has power, ${ }^{113}$ and the authority of charisma is inherent in the Kiai

Referring to the theory of social construction, ${ }^{114}$ the Kiai Kampung externally formed an inclusive variant of Islam to accept bromocorah as an element of acculturation and moderation of Islamic da'wah. The objectivation of local traditions is modified culturally and forced as a form of Islamic acceptance of the bromocorah. Internalization was built by prioritizing aspects of the benefit of the people. Understanding and supporting marginal people ${ }^{115}$ to become hybrids means following the changing changes in society. Kiai's local Islamic design authorizes the diversity and development of Islam in Indonesia which has the potential to color Global Islam without reference to Oliver Roy's global definition of Islam. ${ }^{116}$

The design of the local Islamic authority of the Kiai Kampung is prescriptive, flowing without making an election but, community willingness and commitment. The Kiai's life and role in the community become a role model and reference for the community in determining a religious leader. Work performance that looks small but, has a big impact on the benefit of the people.

112 A. Ajan, Amir Mahruddin and Muhammad Agus Mulyana, "Efektivitas Kepemimpinan Karismatik Kyai dalam Meningkatkan Kinerja Guru," Tadbir Muwabhid, 2, 1 (2018), pp. 33-45.

113 Achmad Zainal Arifin, "Transmitting Charisma: Re-Reading Weber through the Traditional Islamic Leader in Modern Java," Jurnal Sosiologi Reflektif, 9, 2 (2015), pp. 130.

114 Benjamin B. Dunford and Matthew B. Perrigino, "The Social Construction of Workarounds," Advances In Industrial And Labor Relations, 24 (2018), pp. 7-28.

115 Taylor Sweet, "Understanding and Supporting the Transition of Marginalized Students Entering College," Georgia Southern University, International Conference, 7-8 February 2020, p. 24.

116 Oliver Roy, Globalized Islam: The Search for a New Ummab (New York: Columbia University Press, 2013). 


\section{The Formal Marja' and the Theoretisation of Kiai Kampung's Authority on Local Islam}

The Kiai formally and informally becomes the symbol and identity of religion, which constructs local Islam. Max Weber's authority theory consists of three (3) typologies: legal, traditional, and charismatic authority 117 as a reference to find the typology of Kiai's authority. Native Islam became a model of walisongo (nine trustees) by strengthening local Islam. ${ }^{118}$ The diversity of local Islam spread in Indonesia is the creativity and authority of the Kiai. The diversity forms an Islamic identity with a touch of Kiai that constructs local Islam.

The Kiai's authority over local Islamic construction is related to the community group, finding interpretations of social construction. 119 Local Islamic construction in the form of internalization of multicultural locality values by teaching the meaning of pride. The meanings conveyed by Kiai are: first, the transformation of values (informing a certain value) as a discourse of knowledge or knowing phase. Second, value transactions (there are reciprocal interactions to conduct value transactions) or the doing phase and third, value interactions that are accompanied by an implementation or being phase.

Externalization of local Islamic construction shapes the diversity and identity construction of a village. Identity strengthened the existence of the village community formed by Kiai and further strengthened his excellence and wisdom. The Kiai creates a product or concept of local Islam continuously. ${ }^{120}$

Kiai's efforts in constructing local Islam provide an accommodative space for bromocorah (marginal) in expressing local traditions integrated with Islam. The value of local Islamic objectivity gives a new color to mutual understanding and finds that Kiai is very

117 David Beetham, Max Weber and the Theory of Modern Politics (London: Alan and Unwin, 1974), pp. 151-155.

118 Ahmad Ubaidilah, "Islam Formalis Versus Islam Lokalis: Studi Pribumisasi Islam Walisongo dan Kiai Ciganjur,” Jurnal Addin, 10, 1 (2016), pp. 233-262.

119 Marlon Barbehön, "Reclaiming Constructivism: Towards an Interpretive Reading of the 'Social Construction Framework,"' Policy Sciences, 53, 1 (2020), pp. 139-160.

120 Mudrik Al Farizi, "Realitas Konstruksi Sosial: Kekuasaan Kiai dalam Mengonstruksi Keluarga Sakinah pada Masyarakat Ngawi," Al-Mabsut: Jurnal Studi Islam dan Sosial, 13, 1 (2019), pp. 60-71. 
wise in constructing local Islam. Not doing discrimination to anyone including, giving freedom to marginal groups.

The position of the Kiai in the community is at the center of community policy and discussion. His presence as a religious leader is not done by election but by community agreement. The Kiai Kampung in the theory of rules is called the formal 'marja'121 because chosen based on Islamic law, it is not done in detail. In Islamic countries such as Saudi Arabia, Iran, Brunei Darussalam state leaders and religious authorities based on the authority of previous leaders and formalities. The authority of the leader established based on the formality can consider and attitude or will because, approval by certain rules as it happens in a country.

In the case of the Iraqi leader after the fall of Saddam Hussein 2003, Ali al-Sistani was a key player in the process of forming and defending Iraqi politics but, Sistani did not have an official position in Iraq. This means that there is no constitutional status for Sistani but, Sistani's authority has been roughly formalized which was adopted by the 2003 law. Formalization forms a unique relationship between the state and the Shiite religious authority in certain rules to obscure the boundaries between formality and informality. ${ }^{122}$ That is, the role of al-Sistani as a senior Kiai in Iraq has a prescriptive attitude towards religious authority.

Kiai Kampung has an authoritative role that exceeds the authority of formal leaders from various aspects of the field. In the political aspect, the Kiai is seen as a charismatic leader thereby obediencethat is able to hegemony the community is formed consciously without coercion. Sowan or visiting to ask for Kiai's guidance ${ }^{123}$ is used as a barometer for the success of politicians to reach their peak careers.

Kiai's authority not only plays a role but, with an aesthetic sensibility lens. The superiority of moral or character and wisdom of the Kiai form the obedience of the community. The Kiai Kampung forms a traditional authority that has undergone a process of

121 Harith Hasan Al-Qarawee, "The 'Formal' Marja': Shi'i Clerical Authority and the State in Post-2003 Iraq," British Journal of Middle Eastern Studies, 46, 3 (2019), pp. 481497.

122 Al-Qarawee, “The 'Formal' Marja',” pp. 490-497.

123 Zuliansyah, “Sowan Kyai, Komunikasi Perspektif Islam-Jawa,” pp. 95-104. 
transformation ${ }^{124}$ by not referring to the rules of the text but, following the desires of the marginal community or bromocorah to make them aware in a wise way.

The Kiai's authority on the socio-cultural aspect plays a maximum role as evidenced by his absolute decision. The role of the Kiai becomes a mediator between communities, in seeing social cases ${ }^{125}$ such as; crime, different views even, the gap between ideologies. Kiai's fragmentation becomes an analysis to find arguments from the standpoint of the ethical construction of society. ${ }^{126}$ Formal and nonformal always accompany every decision by involving Kiai. As the religious authority in East Asia is focused on the lens of aesthetics there is an emotional connection and aesthetic standards that interfere with the classical definitions and types of authority. ${ }^{127}$ Therefore, the negotiation of the authority of the Kiai is carried out by legitimizing the authority and contingency and instability from time to time.

Kiai's authority is related to the piety of Muslims in carrying out worship in the mosque. Social piety ${ }^{128}$ was also a concern of Kiai; by donating his wealth from each rice harvest. The community follows these rules for the prosperity of the mosque. Building an Islamic economy with social piety oriented, Kiai developed through the charity zakat and infaq boxes. The management of the mosque in the form of financial assistance can be adapted to the Deobandi approach namely, an approach that focuses on the importance of control so that there is no misuse and struggle. ${ }^{129}$ Local Islamic construction in the economic

124 Benno Netelenbos, "Bringing Back Max Weber into Network Governance Research," Critical Policy Studies, 14, 1 (2020), pp. 67-85.

125 Ismail and Moh Wardi, "Peran Kiai dalam Rekonsiliasi Sosial Pasca Carok Massal di Bujur Tengah Pamekasan Madura," Jurnal Kajian Islam dan Budaya, 17, 1 (2019), pp. 128-152.

126 Fazlul Rahman, "Managing the Consequences of the Fragmentation of Religious Authority: Lessons Learned from Malaysia and Singapore," Religió: Jurnal Studi AgamaAgama, 10, 1 (2020), pp. 26-53.

127 Erica Baffelli, "Religious Authority in East Asia Materiality, Media, and Aesthetics," Asian Ethnology, 78, 1 (2019), pp. 3-23.

128 Mahmudah Mulia Muhammad, "Membangun Sistem Ekonomi Islam Berorientasi Kesalehan Sosial," El-Iqtishady, 1, 1 (2019), pp. 33-42.

129 Sana Haroon, "Contextualizing the Deobandi Approach to Congregation and Management of Mosques in Colonial North India," Journal of Islamic Studies, 28, 1 (2017), pp. 68-93. 
aspects of the village besides, waqf land in the form of rice fields and donations, then it needs to be controlled or supervised.

The Kiai's authority interfered with power so that his charisma had unlimited authority. Charisma is a gift of community trust because of, the role and devotion to the community. Within the scope of the state, the charisma of leaders such as Mahathir Mohammad is a formal leadership that politically has power, control, stability, and defense. ${ }^{130}$ The inherent charisma can be interpreted as a formal marja which has authoritative status. The authority of the Kiai Kampung charisma is limited by the village or village by referring to the religious sector. Formal "marja" becomes the spirit for the prescriptive authority of the Kiai in constructing local Islam with various concepts in the Kiai's view. Local Islam became the identity in developing Islam by maintaining the limits of religious teachings against the authority of the Kiai. Accommodative Islam is a choice so that there is no debate with the pros and cons of designing local Islam. Accommodative Islam ${ }^{131}$ is the right choice to review the values of contemporary Islam ${ }^{132}$ so that there is no a priori, hence the development of global Islam could advance.

\section{Conclusion}

Based on the analysis of local Islamic construction in the context in Ngawi; Local Islam is a variant of Islam that was developed by the Kiai Kampung in an authoritative manner. The role and authority of the Kiai are able to penetrate various aspects or fields; economic, political, and social culture. Local Islam accommodates the wishes of the people without selective logging. Authority functions as a method to accommodate bromocorah or marginal people to produce accommodative local Islamic constructions.

The authoritative role of the Kiai in constructing local Islam teaches the public about obedience and obedience to leaders who master the breadth and depth of religious knowledge. Authority

\footnotetext{
130 Suleyman Temiz and Arshad Islam, "Charismatic Political Leadership and Tun Dr Mahathir Mohamad's Malaysia: Power, Control, Stability and Defence," Intellectual Discourse, 27, 2 (2019), pp. 475-505.

131 Edy Susanto and Karimullah, "Islam Nusantara: Islam Khas dan Akomodatif terhadap Budaya Lokal,” al-Ulum, 6, 1 (2016), pp. 56-80.

132 Muhammad Syukri Salleh, "Revisiting Contemporary Islamic Values," Researchers World: Journal of Arts, Science and Commerce, 10, 4 (2019), p. 38.
} 
becomes the right of religious leaders to convey religious messages. Interpreting religion is not only ritual worship related to the creator of the universe but, interacting with humans and the environment is part of religious teachings. Following the fact that local Islam is one of the models for the development of multicultural Indonesian Islam with distinctive local Javanese variants, Kiai has moral excellence and exemplary for the community as a charismatic leader, allowing him to become the formal marja' for the society.

The Kiai's authority becomes a prescriptive identity (giving directions and provisions). Charismatic Kiai has the authority to give orders with his authority. Kiai's decision is ensured through his policies which are generally not opposed by the community. Prescriptive as community obedience to Kiai who is believed to be correct in every decision. The figure of the Kiai Kampung is a reproduction of the pesantren Kiai which has a correlation in developing a progressive society.

The Kiai Kampung authority is a movement of religious activities, building spirituality, and social development. The existence of Kiai underwent a process of transformation that, Kiai can also be involved directly or indirectly in the world of politics. The involvement of the Kiai in various roles can be beneficial to strengthen the foundations of Islamic teachings, as the role of the Prophet not only improves human morals but, teaches Islam by building civilizations. Islam in Indonesia is a representation of the construction of local Islam and the Kiai Kampung as a decision-maker has the potential to color the development of global Islam. []

\section{References}

Ajan, A., Amir Mahruddin and Muhammad Agus Mulyana. "Efektivitas Kepemimpinan Karismatik Kyai dalam Meningkatkan Kinerja Guru." Tadbir Muwabbid, 2, 1 (2018), pp. 33-45.

al-Farizi, Mudrik "Realitas Konstruksi Sosial: Kekuasaan Kiai dalam Mengonstruksi Keluarga Sakinah pada Masyarakat Ngawi." AlMabsut: Jurnal Studi Islam dan Sosial, 13, 1 (2019), pp. 60-71. 
Al-Qarawee, Harith Hasan. "The 'Formal' Marja': Shi 'i Clerical Authority and the State in Post-2003 Iraq." British Journal of Middle Eastern Studies, 46, 3 (2019), pp. 481-497.

Andrias, M. Ali, et al. "Model Kepemimpinan Politik Kyai: Studi Peran Kyai dalam Pergeseran Perilaku Politik Massa NU, PKB, dan PPP.” Politika: Jurnal Ilmu Politik, 7, 2 (2016), pp. 21-33.

Anita, Dewi Evi. "Walisongo: Mengislamkan Tanah Jawa; Suatu Kajian Pustaka." Wahana Akademika: Jurnal Studi Islam dan Sosial, 1, 2 (2014), pp. 243-266.

Arifin, Achmad Zainal. "Transmitting Charisma: Re-Reading Weber through the Traditional Islamic Leader in Modern Java." Jurnal Sosiologi Reflektif, 9, 2 (2015), pp. 1-30.

Asroni, Ahmad. "Islam dan Bina Damai: Ikhtiar Membumikan Doktrin Islam yang Rahmatan Lil 'Alamin." Titian: Jurnal Ilmu Humaniora, 3, 2 (2019), pp. 222-240.

Babbie, Earl. The Basics of Social Research. London: Cengage Learning, 2007.

Barbehön, Marlon. "Reclaiming Constructivism: Towards an Interpretive Reading of the "Social Construction Framework." Policy Sciences, 53, 1 (2020), pp. 139-160.

Basyir, Kunawi. 'The 'Acculturative Islam' as a Type of Home-Grown Islamic Tradition: Religion and Local Culture in Bali." Journal of Indonesian Islam, 13, 2 (2019), pp. 326-349.

Beatty, Andrew. Varieties of Javanese Religion an Antropological. New York: Cambridge University Press, 2003.

Beetham, David. Max Weber and the Theory of Modern Politics. London: John Wiley \& Sons, 2018.

Berman, Ruth A. Usage-Based Studies in Modern Hebrew: Background, Morpho-Lexicon, and Syntax. Philadelphia: John Benjamins Publishing Company, 2020.

Bloom, Paul. "Religion, Morality, Evolution." Annual Review of Psychology, 63, 1 (2012), pp. 179-199.

Boogert, Jochem van Den. "The Role of Slametan in the Discourse on Javanese Islam.” Indonesia and the Malay World, 45, 133 (2017), pp. 352-372. 
Díez-Esteban, José María, Jorge Bento Farinha and Conrado Diego García-Gómez. "Are Religion and Culture Relevant for Corporate Risk-Taking? International Evidence." Brq Business Research Quarterly, 22, 1 (2019), pp. 36-55.

Dirdjosanjoto, Pradjarta. Memelihara Umat; Kiai Pesantren-Kiai Langgar di Jawa. Yogyakarta: LKiS, 1997.

Dunford, Benjamin B. and Matthew B. Perrigino. "The Social Construction of Workarounds." Advances in Industrial and Labor Relations, 24 (2018), pp. 7-28.

Fatoni, Ahmad. "Hubungan antara Kyai Kampung dan Kyai Pesantren." Koran Bhirawa, 17 February 2020.

Fox, James J., and Muhaimin A. G. "Foreword". The Islamic Traditions of Cirebon, Ibadat and Adat among Javanese Muslims. Canberra: ANU Press, 2006.

Geertz, Clifford. "The Javanese Kijaji: The Changing Role of a Cultural Broker." Comparative Studies in Society and History, 2, 2 (1960), pp. 228-249.

---------. The Interpretation of Cultures. New York: Basic Books, 1973.

-------. The Religion of Java. Chicago: University of Chicago Press, 1976.

Roy, Oliver. Globalized Islam: The Search for a New Ummah. New York: Columbia University Press, 2013.

Hadi, Murtado. Jejak Spiritual Kiai Jampes. Jakarta: Pustaka Pesantren, 2008.

Hadiryandono, Muhammad Nafik. "Sosial Ekonomi Pondok Pesantren Perspektif Sejarah." Mozaik Humaniora, 18, 2 (2018), pp. 189-204.

Haroon, Sana. "Contextualizing the Deobandi Approach to Congregation and Management of Mosques in Colonial North India." Journal of Islamic Studies, 28, 1 (2017), pp. 68-93.

Hilmy, Masdar. "Towards a Religiously Hybrid Identity? The Changing Face of Javanese Islam.” Journal of Indonesian Islam, 12, 1 (2018), pp. 45-68.

Husain, Ed. The House of Islam: A Global History. London: Bloomsbury Publishing, 2018. 
Idawati, and Benni Handayani. "Communication Strategy Planning of Majelis Taklim in Implementation Recitation Program." International Journal of Media and Communication Research, 1, 1 (2020), pp. 41-46.

Kadim, A., Nardi Sunardi, Rosa Lesmana and Asep Sutarman. "Revitalisasi Fungsi Masjid sebagai Pusat Penguatan Manajemen Peternak Sapi Rakyat melalui Lembaga Pemberdayaan Masyarakat Terpadu (Lempermadu); Studi Kasus di Masjid Ainul Yaqin Kel. Jontlak, Kec. Praya, Kab. Lombok Tengah, Provinsi Nusa Tenggara Barat." Jurnal Abdi Masyarakat Humanis, 1, 1 (2019), pp. 10-20.

Kitiarsa, Pattana. Religious Commodifications in Asia: Marketing Gods. London: Routledge, 2007.

Kurniati, Mia, Miftahus Surur and Ahmad Hafas Rasyidi. "Peran Kepemimpinan Kyai dalam Mendidik dan Membentuk Karakter Santri yang Siap Mengabdi kepada Masyarakat." Al-Bayan: Jurnal Ilmu Al-Qur'an dan Hadist, 2, 2 (2019), pp. 194-203.

Kurniawan, Syamsul. "Masjid dalam Lintasan Sejarah Umat Islam." Jurnal Khatulistiwa - Journal of Islamic Studies, 4, 2 (2014), pp. 169184.

Luthfi, Khabibi Muhammad. "Islam Nusantara: Relasi Islam dan Budaya Lokal." Shabih: Journal of Islamicate Multidisciplinary, 1, 1 (2016), pp. 1-12.

Mahmud, Adilah. "Hakikat Manajemen Dakwah." Palita: Journal of Social Religion Research, 5, 1 (2020), pp. 65-76.

Manger, Leif O. Muslim Diversity: Local Islam in Global Contexts. London: Routledge, 2013.

Muchtar, Ah Mutam. "Potret Pendidikan Pesantren dalam Film 'Sang Kyai." Jurnal Pemikiran dan Ilmu Keislaman, 2, 1 (2019), pp. 82-124.

Mundiri, Akmal and Afidatul Bariroh. "Transformasi Representasi Identitas Kepemimpinan Kyai dalam Hubungan Atasan dan Bawahan.” Al-Idarah: Jurnal Kependidikan Islam, 8, 2 (2018), pp. 234-255.

Muslim, Ahmad Shobiri. “Urgensi Materi Khatib Jum'at Kyai-Kyai Kampung sebagai Upaya Gerakan Deradikalisasi Agama di Kabupaten Kediri." Spiritualita, 2, 1 (2018), pp. 101-120. 
Muzakki, Akh. "Transmitting Islam through Stories: The Sociology of Production and Consumption of Islam in Novel Literature." Journal of Indonesia Islam, 11, 1 (2017), pp. 59-76.

Netelenbos, Benno. "Bringing Back Max Weber into Network Governance Research." Critical Policy Studies, 14, 1 (2020), pp. 67-85.

Octarina, Mita and Tina Afiatin. "Efektivitas Pelatihan Koping Religius untuk Meningkatkan Resiliensi pada Perempuan Penyintas Erupsi Merapi." JIP, Jurnal Intervensi Psikologi, 5, 1 (2013), pp. 95110.

Omartian, Stormie. The Power of Praying Together: Prayer and Study Guide. Harvest House Publishers, 2003.

Pramono, Didi. "The Authority of Kyai toward the Santri: A Review of Gender Construction at Pondok Pesantren." Komunitas: International Journal of Indonesian Society and Culture, 10, 1 (2018), pp. 92-100.

Rahman, Ratnah. "Peran Agama dalam Masyarakat Marginal." Sosioreligius, 4, 1 (2019), pp. 80-89.

Roberts, Kenneth. Youth and Leisure. London: Routledge, 2019.

Sahrasad, Herdy. "Review of Islam, State and Society in Indonesia: Local Politics in Madura by Yanwar Pribadi." Southeast Asian Studies, 8, 2 (2019), pp. 331-335.

Saifullah. KH. Badri Mashduqi: Kiprah dan Keteladanan. Yogyakarta: LKiS, 2008.

Setiawan, Satria and Budi Sujati. "Gambaran Ahmad Dahlan dan Wahab Hasbullah dalam Pendidikan Islam terhadap Nasionalisme Indonesia." Al-Fikri: Jurnal Studi dan Penelitian Pendidikan Islam, 2, 1 (2019), pp. 28-36.

Setiyani, Wiwik. "Agama sebagai Perilaku Berbasis Harmoni Sosial; Implementasi Service Learning Matakuliah Psikologi Agama." Community Engagement (2016).

--------. "Implementasi Psikologi Humanistik Carl Rogers pada Tradisi Lokal Nyadran di Jambe Gemarang Kedunggalar Ngawi.' Islamica: Jurnal Studi Keislaman, 12, 1 (2017), pp. 230-257. 
Sidiq, Mahfudz. "Pergeseran Pola Kepemimpinan Kiai dalam Mengembangkan Lembaga Pesantren." Falasifa: Jurnal Studi Keislaman, 11, 1 (2020), pp. 144-156.

Sumbulah, Umi. "Islam Jawa dan Akulturasi Budaya: Karakteristik, Variasi dan Ketaatan Ekspresif." El-Harakah, 14, 1 (2012), pp. 51-68.

Susanto, Fajar and Triana Novitasari. "Bentuk Kreativitas Pemuda Karang Taruna dalam Pembangunan Desa Bening." Jurnal Penamas Adi Buana, 2, 2 (2019), pp. 25-28.

Umami, Ida. "Peran Tokoh Agama dalam Pembinaan Harmonisasi Kehidupan dan Akhlak Masyarakat di Kota Metro Lampung." Fikri: Jurnal Kajian Agama, Sosial dan Budaya, 3, 1 (2018), pp. 259276.

Watts, Logan L., Logan M. Steele, Kelsey E. Medeiros, and Michael D. Mumford. "Minding the Gap Between Generation and Implementation: Effects of Idea Source, Goals, and Climate on Selecting and Refining Creative Ideas." Psychology of Aesthetics, Creativity, and the Arts, 13, 1 (2019), pp. 2-14.

Woodward, Mark. "Java, Indonesia and Islam." Muslims in Global Societies Series. Netherlands: Springer, 2011.

Zuliansyah, Muhammad Alfien. "Sowan Kyai, Komunikasi Perspektif Islam-Jawa.” Komunikator, 9, 2 (2017), pp. 95-104.

\section{List of interviews:}

Interview with Agus, Ngawi, 25 March 2019.

Interview with Anas, Ngawi, 22 March 2019.

Interview with Jarwati, Ngawi, 15 March 2019.

Interview with Jono, Ngawi, 17 March2019.

Interview with Khudhori, Ngawi, 21 March 2019.

Interview with Kumini, Ngawi, 12 March 2019.

Interview with Kumini, Ngawi, 24 March 2019.

Interview with Maskuruddin, Ngawi, 14 March 2019.

Interview with Miskan, Ngawi, 28 March 2019.

Interview with Slamet, Ngawi, 16 March 2019. 
Wiwik Setiyani

Interview with Sri Muryati, Ngawi, 20 March 2019.

Interview with Sumarsono, Ngawi, 18 March 2019.

Interview with Sumarsono, Ngawi, 19 March 2019.

Interview with Sumarsono, Ngawi, 28 March 2019.

Interview with Wajinah, Ngawi, 20 March 2019.

Interview with Zaini, Ngawi, 23 March 2019. 